Mots. Les langages du politique

78 | 2005

Usages politiques du genre

Anne-Marie Houdebine-Gravaud (éd.), La féminisation des noms de métiers. En français et dans d'autres langues

Valérie Brunetière

\title{
OpenEdition
}

Journals

Édition électronique

URL : https://journals.openedition.org/mots/460

DOI : $10.4000 /$ mots.460

ISSN : 1960-6001

Éditeur

ENS Éditions

Édition imprimée

Date de publication : 1 juillet 2005

Pagination : 155-155

ISBN : 2-84788-080-1

ISSN : 0243-6450

Référence électronique

Valérie Brunetière, «Anne-Marie Houdebine-Gravaud (éd.), La féminisation des noms de métiers. En français et dans d'autres langues », Mots. Les langages du politique [En ligne], 78 | 2005, mis en ligne le 31 janvier 2008, consulté le 23 avril 2022. URL : http://journals.openedition.org/mots/460 ; DOI : https:// doi.org $/ 10.4000 /$ mots. 460 
pratiques, y compris scientifiques, est bien une question politique. Comme le souligne ailleurs Mona Ozouf à propos des mots pour dire le féminin, la représentation la plus fonctionnelle de la différence consiste à opposer «des hommes collectivement coupables à des femmes collectivement victimes ${ }^{10}$ : or c'est précisément la naturalisation de la différence des sexes qui fait qu'on peine à se la figurer autrement, comme un différend entre les sexes.

Aurélie Tavernier

Université Lille 3, GERICO, aurelie.tavernier@univ-lille3.fr

\section{La féminisation des noms de métiers. En français et dans d'autres langues}

Anne-Marie Houdebine-Gravaud (éd.)

1998, Paris, L'Harmattan, 196 p.

Si on parlait plus souvent d'une ministre de la Justice, d'une Garde des Sceaux, n'y aurait-il pas davantage de vocations politiques chez les femmes?

Nommer les femmes au féminin dans leurs fonctions est une façon de les faire apparaître dans la vie sociale. Le président de la République et le Premier ministre, en décembre 1997, ont déclaré soutenir l'action des ministres femmes désirant être désignées au féminin. Dix ans auparavant, une commission de terminologie, présidée par Benoîte Groult à la demande d'Yvette Roudy, réunissait des experts linguistes, dont Anne-Marie Houdebine, professeur à l'université Paris 5 et sous la direction de laquelle cet ouvrage a paru. Cette commission produisit la circulaire du 11 mars 1986 relative à la féminisation des noms de métiers, titres et fonctions.

Cet ouvrage rend compte des recherches menées alors, de même qu'il fait l'état des lieux de la question, dix ans après, dans les usages oraux et les discours écrits. Il propose également un détour par d'autres langues plus ou moins proches ou différentes du français (québécois, créole martiniquais, russe, arabe, coréen et hongrois). Ces dernières permettent de mettre en évidence le rôle particulier de l'utilisation du féminin pour la nomination des femmes.

Valérie Brunetière

Université Paris 5, DYNALANG, valbrune@wanadoo.fr

10. M. Ozouf, 1995, Les Mots des femmes. Essai sur la singularité française. Paris, Fayard, (L’Esprit de la cité), p. 11. 